\title{
As lost as a pun in a corpus: an investigation into noncanonical phraseological occurrences in large corpora and translation
}

\author{
Mais perdido que trocadilho num \\ corpus: estudo de ocorrências \\ fraseológicas não-canônicas em \\ grandes corpora e tradução
}

Adauri Brezolin*

* Professor-titular do Curso de Letras - Língua Estrangeira, Universidade Metodista de São Paulo. E-mail: brezolinadau@yahoo.com.br

TradTerm, São Paulo, v.37, n. 2, janeiro/2021, p. 460-487 Número Especial - Linguística de Corpus 
Abstract: Although it might appear contradictory to investigate noncanonical phraseological combinations in corpora, corpus linguistics research has revealed that they exceed canonical forms in number (PHILIP 2008). This paper intends to discuss the idea of fixedness by analyzing variant forms of idioms, and if they qualify as wordplay. The Web, our data source, is employed for collecting such noncanonical occurrences in both English and Portuguese using keywords on the Google Search Engine. Our discussion mainly draws on studies relating to fixed phrases (KJELLMER 1991; GRANGER \& PAQUOT 2008; TAGNIN 2013); phraseological skeletons (RENOUF \& SINCLAIR 1991; PHILIP 2008), and idiom transformations (VEISBERGS 1997; BARTA 2005). Due attention is also given to search queries of nonstandard forms of fixed expressions in corpora (PHILIP 2008), and the translation of idiom-based wordplay (VEISBERGS 1997; BREZOLIN 2020).

Keywords: Corpus Linguistics; Non-canonical phraseology; Wordplay; Translation.

Resumo: Embora possa parecer contraditório investigar combinações fraseológicas não-canônicas em corpora, pesquisas baseadas em linguística de corpus revelam que formas não-padrão excedem as formas canônicas (PHILIP 2008). Este artigo discute a ideia de fixidez, analisando variações de unidades fraseológicas, e se resultam em jogos de palavras. A Web é usada para a recolha de tais ocorrências não-canônicas em inglês e português por intermédio de palavras-chave no Motor de Busca Google. Nossa discussão nutre-se principalmente de estudos relacionados a expressões fixas (KJELLMER 1991; GRANGER \& PAQUOT 2008; TAGNIN 2013); esqueletos fraseológicos (RENOUF \& SINCLAIR 1991; PHILIP 2008), e transformações fraseológicas (VEISBERGS 1997; BARTA 2005). Procedimentos de busca de formas não-canônicas em corpora e a tradução de jogos de palavras fraseológicos (VEISBERGS 1997; BREZOLIN 2020) também receberão a devida atenção.

Palavras-chave: Linguística de corpus; Fraseologia não-canônica; Jogo de palavras; Tradução.

TradTerm, São Paulo, v.37, n. 2, janeiro/2021, p. 460-487

Número Especial - Linguística de Corpus

www.revistas.usp.br/tradterm 


\section{Introduction}

Investigating noncanonical phraseological occurrences in corpora might at first appear contradictory since phraseology has put in a great deal of effort into identifying canonical forms, and corpus linguistics has sought to encounter regularity and consistency of fixed, recurrent combinations (PHILIP 2008); however, "corpus linguists have consistently noticed that canonical forms are not particularly common in language corpora and, crucially, they tend to be outnumbered by noncanonical variants and exploitations" (PHILIP 2008: 95). Besides, it is widely accepted that patterns governing idiom transformations are unpredictable, and normally encountered by chance, making their retrieval a hard task, unless they happen to appear "in newspaper and advertising language" (VEISBERGS 1997: 95), in very conspicuous ways.

PHILIP (1998: 106), however, seems to be more optimistic by stating that, although variant forms of fixed expressions are unpredictable, they "can be found in corpora by following quite simple procedures", discussed further on. Based on such enticing prospects, this paper intends to verify if certain search queries can retrieve variant forms of fixed expressions, in English and Portuguese, on the Web. Occurrences will be analyzed in reference to studies on fixed phrases (KJellmer 1991; Granger; Paquot 2008; TAGnin 2013); phraseological skeletons (RenOuF; SINCLAIR 1991; PHILIP 2008), and idiom transformations (VEISBERGS 1997). Special attention is given to structural idiom transformations to verify if they constitute wordplay, and how they can be translated.

\section{Theoretical framework}

Before going into the aspects involved in generating wordplay, it is important to define phraseologism, and Gries' definition is a useful starting point:

the co-occurrence of a form or a lemma of a lexical item and one or more additional linguistic elements of various kinds which functions as one semantic unit in a clause or a sentence and whose frequency

TradTerm, São Paulo, v.37, n. 2, janeiro/2021, p. 460-487 Número Especial - Linguística de Corpus www.revistas.usp.br/tradterm 
of co-occurrence are larger than expected on the basis of chance (2008: 3).

It can be inferred, then, that phraseologisms refer to diverse linguistic phenomena comprising a wide range of combinations that are fixed and idiomatic. According to Kjellmer:

A large part of our mental lexicon consists of combinations of words that customarily co-occur. The occurrence of one of the words in such a combination can be said to predict the occurrence of the other(s). (1991: 112)

Accordingly, this implies that, in the real world, speakers of a language tend to "arrange words in groups" and "use the same arrangement whenever the need arises rather than to rearrange the words or to choose alternative ways of expression" (1991: 114), and this tendency of making "use of chunks of prefabricated matter" allows speakers of a language "to move swiftly through the discourse, and [..] as listeners we expect other speakers to behave in the same way" (KJELLMER 1991: 123). To a certain extent, this holds true since users of a language can resort to different types of "fixed" combinations, or phrasemes (GRANGER; PAQUOT 2008), or consecrated expressions (TAGNIN 2013).

Thus, first impressions might suggest that such arrangements of words or phraseologisms are quite fixed, implying regularity and recurrence. SINCLAIR, however, by providing evidence from corpus data, demonstrates that the "socalled 'fixed phrases' are not in fact fixed” (1996 apud PHILIP 2008: 96, emphasis in original).

Philip (2008) agrees by adding that "canonical forms often include grammatical elements which inflect in text, and they may also have alternative lexical realizations", and illustrates this with the generic term phraseological skeletons. To Philip, the "core components of a phraseological unit constitute its skeleton, which is fleshed out by elements with a less central role in creating and maintaining the structure of a phraseological form" (p. 97). This means that, although certain combinations, at first sight, appear to be unalterable, they are in fact susceptible to different types and degrees of variation.

TradTerm, São Paulo, v.37, n. 2, janeiro/2021, p. 460-487 Número Especial - Linguística de Corpus www.revistas.usp.br/tradterm 
According to Veisbergs, some variations of phraseological units ${ }^{1}$ can be understood as manipulations carried out by an author "to produce stylistic effect by creating a contrast with the 'normal' reading of the idiom in its unchanged form and so defeating the reader's or the listener's expectation" (1997: 157, emphasis in original). The motivated and expressive intention of modifying the standard form of an idiom normall implies creating wordplay, producing an effect of surprise (KJELLMER 1991), of irony and humor (PHILIP 2008), as well as of humor and criticism (BREZOLIN 2020), for instance.

In this paper, two types of phraseologisms, a simile and an idiom, in English and their counterparts in Portuguese, have been chosen for analysis (Figure 1):

Figure 1. Phraseologisms in English and Portuguese selected for analysis

\begin{tabular}{|l|l|l|}
\hline \multicolumn{1}{|c|}{ English } & \multicolumn{1}{c|}{ Portuguese } \\
\hline Simile & (1) as lost as a duck in the desert & $\begin{array}{l}\text { (2) mais perdido que cego em tiroteio } \\
\text { (as lost as a blind man in a shoot-out) }\end{array}$ \\
\hline Idiom & (3) to kill two birds with one stone & $\begin{array}{l}\text { (4) matar dois coelhos de/com uma } \\
\text { cajadada só } \\
\text { (to kill two rabbits with only one blow) }\end{array}$ \\
\hline
\end{tabular}

According to Granger \& Paquot (2008: 43):

similes are "sequences of words that function as stereotyped comparisons. They typically consist of sequences following the frames 'as ADJ as (DET) NOUN' and 'VERB like a NOUN'. Examples: as old as the hills, to swear like a trooper", and

idioms refer to "phrasemes that are constructed around a verbal nucleus. Idioms are characterized by their semantic non-compositionality, which can be the result of a metaphorical process. Lack of flexibility and marked syntax are further indications of their idiomatic status. Examples: to spill the beans, to let the cat out of the bag, to bark up the wrong tree".

\footnotetext{
1 In the literature of phraseology, terms related to phraseological units abound such as collocations, idiomatic constructions, idioms, phrasemes, phraseological constructions, phraseologisms, set expressions, among others.

2 From now on, examples in Portuguese are literally translated into English.

TradTerm, São Paulo, v.37, n. 2, janeiro/2021, p. 460-487

Número Especial - Linguística de Corpus

www.revistas.usp.br/tradterm
} 
Each of the phraseologisms in one language represents its pragmatic correspondent in the other, used figuratively as, "to be deeply distracted, or to have lost focus on or attention of what is happening or what is being said", and "to succeed in achieving two goals in a single action"; respectively. From the structural point of view, this selection reflects the intention of analyzing distinct constructions (within languages), and, from the semantic point of view, combinations with different degrees of idiomaticity: similes usually exhibit a more transparent meaning; idioms, on the other hand, have a more opaque meaning.

It is important to mention that, although phraseologism (1), as lost as a duck in the desert, was only found on the Web; phraseologism (2), mais perdido que cego em tiroteio, was only found in specialist dictionaries (BREZOLIN, ALLEGRO \& MOBAID 2002, 2006), and phraseologisms (3), to kill two birds with one stone, and (4), matar dois coelhos de com/uma cajadada só, were found in both general and specialist dictionaries: THE FreE DictionARY (2020); MERRIAM-WEBSTER (2020), and The Collins COBUILD Dictionary of Idioms (1995); as well as AULETE (2020); Michaelis (2020), and CAMARGo \& STEINBERG (1987); respectively, we have taken for granted that these phraseological occurrences represent canonical forms.

Thus, considering the selected phraseologisms as potential candidates for manipulations, we intend to verify how structures with differences within the language and with similarities across the languages behave in terms of variation and if transformed occurrences constitute wordplay.

We now return to wordplay. For Delabastita (1996: 128):

\footnotetext{
Wordplay is the general name for the various textual phenomenon in which structural features of the language(s) used are exploited in order to bring about a communicatively significant confrontation of two (or more) linguistics structures with more or less similar forms and more or less different meanings.
}

Differently from most definitions, this does not include humor as the intended effect of a deviated use of language. For Veisbergs (1997: 159), however, "(t)he function of most wordplay is to create a comic effect and TradTerm, Sào Paulo, v.37, n. 2, janeiro/2021, p. 460-487 Número Especial - Linguística de Corpus www.revistas.usp.br/tradterm 
attract the attention of the reader or listener to a specific point in the text". Moon (1998: 170), in a less emphatic manner, shares the idea that "the stylistic manipulation of the lexis (and semantics)" of fixed expressions and idioms is "perhaps to provide some sort of defamiliarization, and typically providing humour". A similar opinion is shared by Arnaud, Maniez \& Renner, who define wordplay as "the clever manipulation of the form of a language string or the use of polysemy resulting in an amusing effect" (2015: 136).

Although we are in line with them, we believe that any type of manipulation of the conventionalized use of a linguistic structure, which results in wordplay, is not primarily intended for causing a comic effect, but an initial effect of surprise, due to a construction that defeats the expectation of readers/listeners. It is this initial effect, then, that can trigger subsequent effects of humor, criticism, and so on, depending on extra processing of the phraseological units and their environments.

Regardless of their effect(s), wordplay operate on a cline, revealing that their creation involves mechanisms based on lexical, grammatical, idiomatic, pragmatic aspects, just to mention a few (DELABASTITA 1996; GIORGADZE 2014; TAGNIN 2015a). According to Arnaud, Maniez \& Renner (2015: 139), “(m)any publications include taxonomies of phraseological modifications", like Barta (2005, 2006), whose categories comprise metaplasms; metasemes, and metalogisms, and other subcategories. However, in this paper, our analyses and categorization of idiom modifications will be based on Veisbergs's structural ${ }^{3}$ transformations (addition, insertion, allusion, ellipsis, or substitution) (1997: 158), as well as on Arnaud, Maniez \& Renner's types of modifications (modality, polarity, among others) (2015: 141). Examples will be presented along with our analyses.

When it comes to the extraction of manipulated phraseologisms in language corpora, as already mentioned here, there seems to be "a degree of incompatibility between a methodology which favors the identification of recurrent patterns, and the search for non-recurring variants". Aware of the

\footnotetext{
${ }^{3}$ VIÉGAS-FARIA (2004), DORE (2010), and BREZOLIN (2020), for instance, have investigated wordplay based on semantic idiom transformations.
}

TradTerm, São Paulo, v.37, n. 2, janeiro/2021, p. 460-487

Número Especial - Linguística de Corpus

www.revistas.usp.br/tradterm 
fact that users of a languages can transform phraseological structures in different ways and for different purposes, "how can one search for something without knowing what that something is?" (PHILIP 2008: 96-97).

According to Philip (2008: 100), one way is to focus on the key components of the phraseological unit, that is, on "the most salient elements", which may be syntactic or lexical. Based on the examples of idiom retrieval she demonstrated, and in our experience, it can be inferred that there is no readymade formula for extraction, and language researchers will have to adopt a trial and error approach in search of effective routines; especially when carrying out queries in a large corpus, as we have done here.

For the extraction of manipulated phraseologisms, we used the Web, as our data source, and Google, as our search engine. By using the Web and Google, searches can be conducted in several languages, and different settings and filters can be applied. In all searches, the top menu was adjusted at "News". This decision reflects the idea that idiom manipulations occur in literary works, in advertisements, and "particularly" in journalistic texts (KJeLLMER 1991; PHILIP 2008). As to the languages and regions, English/United States and Brazilian Portuguese/Brazil were selected.

Philip had already drawn attention to the fact that "simple key-word searches" had proved to be "impossible to edit manually", so she had to formulate a series of searches, at the same time, "inclusive of all potentially relevant data" and "restrictive enough to exclude as much 'noise' as possible" (2008: 102, emphasis in original).

\section{Data analysis and results}

Bearing that in mind, we devised and experimented different types of search queries. Table 1 shows the search queries used to extract standard and manipulated forms of the phraseologisms on Google News. 
Table 1: Search query for the extraction of standard and nonstandard phraseological units

\begin{tabular}{c|l}
\hline \multicolumn{1}{c|}{ phraseologisms } & \multicolumn{1}{c}{ search query } \\
\hline (1) as lost as a duck in the desert & 1a. "as lost as" + a duck \\
& 1b. "as lost as" + desert \\
& 1c. "as lost as" \\
\hline (2) mais perdido que cego em tiroteio & 2a. "mais perdido que" + cego \\
& 2b. "mais perdido que" + em \\
& 2c. "mais perdido que" + tiroteio \\
\hline (3) to kill two birds with one stone & 3a. "kill two birds" + with \\
& 3b. "kill" + with one stone \\
\hline (4) matar dois coelhos de/com uma & 4a. "matar dois coelhos" + de \\
cajadada só & 4b. "matar" + coelhos \\
& 4c. "cajadada" + matar \\
\hline
\end{tabular}

All the search queries adopted here, as expected, included constituents of the phraseologisms. Quotation marks were used around either single words or phrases (key elements) to ensure that the exact match would be retrieved by the search engine. Additionally, to the right of these "keywords", the symbol "+" was added for the extraction of possible collocates. For example, 3a implies the occurrence of an idiom variation in which only "one stone" represents the variable slot; 3b, however, implies that "two birds" may be modified, and "one stone" may remain unchanged. It can be observed that the same logic was also applied to extract possible collocates for different elements of the other phraseologisms under investigation. The idea underlying the formulation of these search queries is that manipulated forms are recognizably related to the canonical form (PHILIP 1998).

As expected, some of the routines returned occurrences that had to be left out: a. occurrences in which the selected words appeared separately in different parts of the text (resulting in non-phraseological units); $b$. occurrences in disagreement with the adjusted settings (extracts in British English or European Portuguese, for example), and occurrences that required subscribing to the newspaper containing the searched routine.

After removing noise and redundant hits, the results (extracts as long as four sentences, in general) from each search were copied, pasted into a .txt 
file, and run through with the AntConc concordance tool (ANTHONY 2020) ${ }^{4}$; examples can be seen in the Appendix. It is worth mentioning that, even after excluding interferences; inevitably, much of the analysis had to be carried out manually. As observed, all search queries were deliberately devised to retrieve standard and manipulated forms of the phraseologisms selected for analysis, to verify if both forms occurred in newspaper texts. With reference to the occurrences, they were analyzed only after the results of successive related searches were combined, as PHILIP (1998) stresses. As in any other empirical research, our retrieval procedures invite further refinement, though they have served our purposes successfully.

In Table 2, we can find the total number of occurrences for each idiom. Interestingly, the number of occurrences were inversely proportional when comparing each pair of phraseologism in the two languages.

Table 2: Number of occurrences and percentages of canonical forms for each phraseologism in English and Portuguese

\begin{tabular}{l|c|c|c}
\hline & $\begin{array}{r}\text { number of } \\
\text { occurrences }\end{array}$ & $\begin{array}{r}\text { number of } \\
\text { canonical } \\
\text { forms }\end{array}$ & $\begin{array}{r}\text { percentage of } \\
\text { canonical } \\
\text { forms }\end{array}$ \\
\hline 1. as lost as a duck in the desert & 14 & 1 & $7.1 \%$ \\
\hline 2. mais perdido que cego em tiroteio & 112 & 91 & $81.2 \%$ \\
\hline 3. to kill two birds with one stone & 355 & 338 & $95.2 \%$ \\
\hline 4. matar dois coelhos de/com uma cajadada (só) & 57 & 46 & $80.7 \%$ \\
\hline All & 538 & 476 & $88.5 \%$ \\
\hline
\end{tabular}

Although phraseologisms 1, 2, 3 and 4 were obtained in their entirety (Table 2), only phraseologisms 2,3 , and 4 showed percentages over $80 \%$ of all occurrences. The high frequency of canonical forms seems to contradict the idea that they exceed noncanonical variations in number (PHILIP 2008). Conversely, phraseologism 1 , which showed a very low frequency, only one

4 Unfortunately, KWIC Google - Google search results formatter (CEPRIL, PUC-SP, Brazil), a tool we had used elsewhere (BREZOLIN 2006), which made internet data retrieval much easier, is no longer available.

TradTerm, São Paulo, v.37, n. 2, janeiro/2021, p. 460-487

Número Especial - Linguística de Corpus

www.revistas.usp.br/tradterm 
occurrence, leads us to guess it may not be a canonical form. This will be discussed further down.

Tables 3 and 4 present the occurrences retrieved based on phraseologisms 1 and 2, respectively.

Table 3: Occurrences based on as lost as a duck in the desert extracted on Google News

\begin{tabular}{c|l|c}
\hline \multicolumn{2}{l|}{ Phraseologism 1 } & $\begin{array}{r}\text { number of } \\
\text { occurrences }\end{array}$ \\
\hline & as lost as a duck in the desert & 1 \\
\hline 1A & as lost as a donkey with its head in a hole & 1 \\
$1 \mathrm{~B}$ & as lost as a little boy in a crowded mall & 1 \\
$1 \mathrm{C}$ & as lost as a toddler in a supermarket & 1 \\
$1 \mathrm{D}$ & as lost as an economics professor in an ethics class & 1 \\
$1 \mathrm{E}$ & as lost as a hitchhiker from Timbuktu with severe amnesia & 1 \\
$1 \mathrm{~F}$ & as lost as a seven-day-old puppy released into the wild & 1 \\
$1 \mathrm{G}$ & as lost as a toothbrush at a redneck convention & 1 \\
$1 \mathrm{H}$ & as lost as a townie at the tailgate party & 1 \\
$1 \mathrm{I}$ & as lost as Alice down a rabbit hole & 1 \\
$1 \mathrm{~J}$ & as lost as a nun on honeymoon & 1 \\
$1 \mathrm{~K}$ & as lost as a newborn baby bird & 1 \\
$1 \mathrm{~L}$ & as lost as a tenderfoot & 1 \\
$1 \mathrm{M}$ & as lost as the City of Atlantis & 1 \\
\hline
\end{tabular}

Table 4: Occurrences based on mais perdido que cego em tiroteio extracted on Google News

\begin{tabular}{c|l|c}
\hline \multicolumn{2}{c|}{ Phraseologism 2 } & $\begin{array}{r}\text { number of } \\
\text { occurrences }\end{array}$ \\
\hline 2A & $\begin{array}{l}\text { mais perdido que cego em tiroteio } \\
\text { (as lost as a cookie in a toothless mouth) } \\
\text { mais perdido que cachorro de mudança } \\
\text { (as lost as a moving dog) } \\
\text { 2C }\end{array}$ & $\begin{array}{l}\text { mais perdido que cachorro em dia de mudança } \\
\text { (as lost as a dog on a moving day) } \\
\text { mais perdido que cachorro que caiu do caminhão de mudança } \\
\text { (as lost as a dog that fell off the moving truck) } \\
\text { mais perdido que cachorro cego em tiroteio } \\
\text { (as lost as a blind dog in a shoot-out) } \\
\text { mais perdido que charuto em boca de banguela } \\
\text { (as lost as a cigar in a toothless mouth) } \\
\text { mais perdido que chave em bolsa de mulher } \\
\text { (as lost as a key in a woman's handbag) }\end{array}$ \\
2F
\end{tabular}

TradTerm, São Paulo, v.37, n. 2, janeiro/2021, p. 460-487

Número Especial - Linguística de Corpus

www.revistas.usp.br/tradterm 


\begin{tabular}{c|l|c}
\hline $2 \mathrm{H}$ & $\begin{array}{l}\text { mais perdido que cusco em tiroteio } \\
\text { (as lost as a dog in a shootout) } \\
\text { mais perdido que dinheiro em brecha de sofá } \\
\text { (as lost as money between the couch cushions) } \\
\text { mais perdido que motorista sem carteira } \\
\text { (as lost as a driver without a driver's license) } \\
\text { mais perdido que palhaço em dia de finados } \\
\text { (as lost as a clown on All Saints' Day) } \\
\text { mais perdido que peru bêbado } \\
\text { (as lost as a drunk turkey) } \\
\text { mais perdido que Bolsonaro na presidência } \\
\text { (as lost as Bolsonaro in presidency) } \\
\text { mais perdido que Bolsonaro tentando entender como governar o Brasil } \\
\text { (as lost as Bolsonaro trying to rule Brazil) } \\
\text { mais perdido que chinelo de bêbado na crise dos incêndios na Amazônia } \\
\text { (as lost as a drunkard's shoes in the crisis of Amazonian bush fires) }\end{array}$ & 1 \\
$2 \mathrm{~N}$ & 1 \\
\hline
\end{tabular}

According to Moon, "similes are essentially frames with fossilized lexis: their function is emphasis"; and, as they "serve to intensify adjectives, it is unsurprising that certain common adjectives, or commonly intensified adjectives, occur in frames with varying nouns" (1998: 150). Based on Tables 3 and 4, we can split the idiom into two frames in both languages:

[frame 1] $=[$ AS LOST AS] and [MAIS PERDIDO QUE]

[frame 2] $=[a$ PERSON/an ANIMAL/an OBJECT in/at an either IMPROBABLE or DANGEROUS PLACE]

Frame 1 functions as an adjective and remains unaltered in all occurrences. Frame 2, however, functions as an intensifier, realized through a series of similar combinations based on common attributes or conceptual parameters, a patterning that is systematically reproduced in both languages.

Based on these results, the occurrence as lost as a duck in the desert, which was initially considered as canonical (Table 2), now seems to represent an "established alternative form" (PHILIP 1998: 95). To our understanding, certain linguistic combinations that share similar frames simply co-exist with no reference to a canonical form that could have originated them. As such, they are not context-dependent and can be used interchangeably.

In Portuguese, the situation is almost the same with the difference that there is a canonical form: mais perdido que cego em tiroteio. Similarly, all the

TradTerm, São Paulo, v.37, n. 2, janeiro/2021, p. 460-487 Número Especial - Linguística de Corpus

www.revistas.usp.br/tradterm 
other occurrences, $2 \mathrm{~A}$ to $2 \mathrm{~L}$, are also alternative forms and, then, can be used interchangeably. We call attention to occurrences $2 \mathrm{E}$ (mais perdido que cachorro cego em tiroteio) and $2 \mathrm{H}$ (mais perdido que cusco em tiroteio), which are manipulations of the canonical form by means of substitution, when one or more substrings are replaced with others (ARNAUD, MANIEZ \& RENNER: 2015). The word cego (blind man) was substituted by cachorro cego (blind dog), in 2E, and by cusco (dog), in $2 \mathrm{H}$.

Though the use of unpredictable words associated with highly creative situations produces many humorous combinations, not all the occurrences above could qualify as wordplay, but $2 \mathrm{E}$ and $2 \mathrm{H}$. We may attribute this to the fact that, as the components of the canonical form mais perdido and em tiroteio are semantically very strong and normally associated with cego, different strings defeat the reader's or the listener's expectation, thus creating wordplay.

Three other occurrences in Portuguese deserve our attention:

(2M) mais perdido que Bolsonaro na presidência (as lost as Bolsonaro in presidency);

(2N) mais perdido que Bolsonaro tentando entender como governar o Brasil (as lost as Bolsonaro trying to rule Brazil), and

(20) mais perdido que chinelo de bêbado na crise dos incêndios na Amazônia (as lost as a drunkard's shoes in the crisis of Amazonian bush fires).

All of them are clearly related to the occurrences in Table 4, but differently, their constructions are context-oriented, based on aspects that reflect Brazil's current political and environmental scenery, so, to our understanding, they are seen as "occasional instantiations associated with an idiom base structure", and do not constitute wordplay.

Comparing how phraseologisms 1 and 2 behaved, we must admit that we were initially inclined to categorize all the occurrences for as lost as duck in the desert (Table 3) into occasional variants, as a consequence of their low frequency in our data; however, due to the diversity of semantically-unrelated words in $1 \mathrm{~A}$ to $1 \mathrm{M}$, alternative forms (with no canonical form) seemed to be a more suitable interpretation. The occurrences for mais perdido que cego em

TradTerm, São Paulo, v.37, n. 2, janeiro/2021, p. 460-487 Número Especial - Linguística de Corpus www.revistas.usp.br/tradterm 
tiroteio (Table 4) also posed a similar dilemma, but, based on its higher frequency, we decided to confirm its status as canonical. The other types of occurrences were subdivided into three groups: noncanonical forms, $2 \mathrm{E}$ and $2 \mathrm{H}$, which exhibit substrings of the canonical form; alternative forms, 2A, 2B, 2C, $2 \mathrm{D}, 2 \mathrm{~F}, 2 \mathrm{G}, 2 \mathrm{I}, 2 \mathrm{~J}, 2 \mathrm{~K}, 2 \mathrm{~L}$, which exhibit the same structure, but semanticallyunrelated words, and occasional instantiations associated with an idiom base structure, $2 \mathrm{M}, 2 \mathrm{~N}$ and 20 , which resemble the canonical form, but are highly dependent on specific circumstances.

Next, the occurrences obtained for phraseologisms 3 (kill two birds with one stone) and 4 (matar dois coelhos de/com uma cajadada só) will also be analyzed in reference to the type of modification they have undergone: structural transformations (addition, insertion, allusion, ellipsis, or substitution) (VEISBERGS: 1997) as well as modal and polarity modifications (ARNAUd, MANIEZ \& RenNer: 2015).

In Tables 5 and 6, we present the occurrences for phraseologisms 3 and 4 with the most frequent types of modifications: substitution and addition.

Table 5: Occurrences of kill two birds with one stone, cases of substitution and addition

\begin{tabular}{|c|c|c|}
\hline \multicolumn{2}{|r|}{ Phraseologism 3} & \multirow{2}{*}{$\begin{array}{c}\begin{array}{c}\text { number of } \\
\text { occurrences }\end{array} \\
338\end{array}$} \\
\hline & kill two birds with one stone & \\
\hline $3 \mathrm{~A}$ & kill two birds in one stone & 1 \\
\hline 3B & kill two birds with one act & 1 \\
\hline $3 C$ & kill two birds with one ancient spiritual practice & 1 \\
\hline $3 \mathrm{D}$ & kill two birds with one high-speed stone & 1 \\
\hline $3 \mathrm{E}$ & kill two birds with one Nazi salute & 1 \\
\hline $3 \mathrm{~F}$ & kill two birds with one phone & 1 \\
\hline $3 G$ & kill two birds with one proverbial stone & 1 \\
\hline $3 \mathrm{H}$ & kill two birds with one shot & 1 \\
\hline 31 & kill two birds with one tariff & 1 \\
\hline $3 \mathrm{~J}$ & kill two birds with one update & 1 \\
\hline $3 \mathrm{~K}$ & kill two three birds with one stone & 3 \\
\hline $3 L$ & kill two four birds with one stone (3) & 3 \\
\hline \multirow[t]{2}{*}{$3 M$} & kill many birds with one stone & 1 \\
\hline & & 355 \\
\hline
\end{tabular}

TradTerm, São Paulo, v.37, n. 2, janeiro/2021, p. 460-487

Número Especial - Linguística de Corpus

www.revistas.usp.br/tradterm 
Table 6: Occurrences based on matar dois coelhos de/com uma só cajadada, cases of substitution and addition

\begin{tabular}{|c|c|c|}
\hline \multicolumn{2}{|r|}{ Phraseologism 4} & \multirow{2}{*}{$\begin{array}{c}\begin{array}{c}\text { Number of } \\
\text { occurrences }\end{array} \\
46\end{array}$} \\
\hline & matar dois coelhos de/com uma só cajadada & \\
\hline $4 \mathrm{~A}$ & matar dois coelhos de uma cacetada & 1 \\
\hline 4B & matar dois coelhos com uma chibatada só & 1 \\
\hline $4 C$ & matar dois coelhos em uma paulada & 1 \\
\hline 4D & matar dois coelhos com uma pedra & 1 \\
\hline $4 \mathrm{E}$ & matar dois coelhos com uma porretada só & 1 \\
\hline $4 \mathrm{~F}$ & matar dois coelhos com uma obra só & 1 \\
\hline $4 G$ & matar dois coelhos com um golpe & 1 \\
\hline $4 \mathrm{H}$ & matar dois coelhos com um tiro de canhão & 1 \\
\hline 41 & matar três coelhos com só tomahawk & 1 \\
\hline $4 \mathrm{~J}$ & matar cinco coelhos com uma só cajadada & 1 \\
\hline \multirow[t]{2}{*}{$4 \mathrm{~K}$} & matar duas lebres de uma só cajadada & 1 \\
\hline & All & 57 \\
\hline
\end{tabular}

Analyzing and comparing the above, we can observe similar occurrences in terms of substitution, in both languages, the same frames [kill two birds] [with one stone] and [matar dois coelhos] [de/com uma só cajadada] showed variation.

For instance, in examples 3K, 3L, 3M (in English), and $4 \mathrm{I}$ and $4 \mathrm{~J}$ (in Portuguese), in which two/dois is replaced by other numerals (three, four, five), this strategy seems to indicate an exaggeration of what "one single action" can perform. Probably, a way of maximizing the value of a product or place.

Components of the second frame in both languages were the most modified. In English, stone was replaced for highly semantically-unrelated words (act, ancient spiritual practice, Nazi salute, phone, shot, tariff, update, bone), whereas in Portuguese, cajadada (blow with a rod) was mostly substituted by semantically-related words, or a series of co-hyponyms: cacetada (blow with a stick); chibatada (blow with a whip); paulada (blow with a piece of wood), porretada (blow with a billy club), and golpe (a single blow).

TradTerm, São Paulo, v.37, n. 2, janeiro/2021, p. 460-487 Número Especial - Linguística de Corpus www.revistas.usp.br/tradterm 
We should note that many of them are also phonologically related. We believe that this may be attributable to the fact that some language users, considering that a fixed expression may have acquired a cliché-like character, try to avoid it by replacing a very salient word with co-hyponyms.

In English, phonologically-related words were also used, for example, stone is substituted by phone in 3F. This manipulation is intended for appellative purposes, it is about a telephone advertisement.

In Portuguese, one occurrence is worth mentioning. Example $4 \mathrm{~K}$ is a creative manipulation, in which coelho (rabbit) is replaced with a synonymy lebre (hare), generating, this way, wordplay through reliteralization. According to COULMAS, reliteralization is a process in which "the expression is stripped of its idiomatic meaning" (1979: 145). Also known as remotivation (TAGNIN 2015b) and decrystallization (CARNEIRO 2017), this mechanism is explained by the fact that "a literal meaning of one of the components must be invented in order to achieve the desired effect" (Coulmas 1979: 145), in this case, lebre (hare) is interpreted literally, but combined with the other frames, the figurativeness of the expression is preserved.

Additions, also context-oriented, are usually carried out by modifiers of different word-classes, mainly adjectives and adjectival phrases (highspeed/proverbial stone).

As far as wordplay is concerned, all the occurrences in Tables 3 and 4 can be classified as such, since at least one substring of the canonical form was manipulated, defeating the reader's expectation, as already mentioned. Certainly, some resultant wordplay can be considered more effective than others, matar duas lebres de uma só cajadada is illustrative of this.

Tables 7 and 8 show hybrid cases, combining addition, allusion, deletion, insertion, inversion, modality, polarity, substitution, or single cases of inversion, modality or polarity.

TradTerm, São Paulo, v.37, n. 2, janeiro/2021, p. 460-487

Número Especial - Linguística de Corpus

www.revistas.usp.br/tradterm 
Table 7: Other types and hybrid cases of modification based on kill two birds ...

\begin{tabular}{|c|c|c|c|}
\hline & & category & $\begin{array}{r}\text { number of } \\
\text { occurrences }\end{array}$ \\
\hline $3 \mathrm{~N}$ & $\begin{array}{l}\text { kill three birds with one stone with this Bluetooth } \\
\text { speaker }\end{array}$ & $\begin{array}{l}\text { substitution + } \\
\text { insertion }\end{array}$ & 1 \\
\hline 30 & RBI can kill three birds with one stone by cutting it ... & $\begin{array}{l}\text { modality + } \\
\text { substitution }\end{array}$ & 1 \\
\hline $3 \mathrm{P}$ & Amazon Could Kill Many Birds with This Single Stone & modality + addition & 1 \\
\hline $3 Q$ & $\begin{array}{l}\text { A } \$ 10 \text { billion overseas IPO could kill many birds with one } \\
\text { stone. }\end{array}$ & modality & 1 \\
\hline $3 R$ & It's like we're using one stone to kill two birds. & inversion & 1 \\
\hline $3 S$ & $\begin{array}{l}\text { Why not kill three love birds with one stone and with an } \\
\text { edible bouquet for dinner and dessert? }\end{array}$ & $\begin{array}{l}\text { substitution }+ \\
\text { addition + polarity } \\
\quad+\text { insertion }\end{array}$ & 1 \\
\hline \multirow[t]{2}{*}{$3 \mathrm{~T}$} & $\begin{array}{l}\text { We prefer Ricky's version to the original, not only because } \\
\text { it's presumably a lot easier to get two birds stoned than } \\
\text { it is to kill two birds with one stone, but because why } \\
\text { would you even want to kill one bird, let alone two? }\end{array}$ & $\begin{array}{l}\text { passivization + } \\
\text { substitution + } \\
\quad \text { allusion }\end{array}$ & 1 \\
\hline & All & & 7 \\
\hline
\end{tabular}

Some of these categories are self-explanatory: insertion, a new string is positioned, usually, at a final position ( $3 \mathrm{~N}, 3 \mathrm{~S})$; no initial position was found in our data; inversion, one substring occupies the place of another (3R); modality refers to cases in which a modal verb is added to the expression (3O, 3P, 3Q); polarity indicates shifts in the way the expression is constructed (affirmatively, negatively or interrogatively); $3 \mathrm{~S}$, which contains other types of modification, is an illustrative case of the procedure. Example $3 \mathrm{~T}$ is by far the most creative, it contains an unusual modification in a central element, two is replaced by one; the verb to kill is alluded in the final question, and passivization, reasonably infrequent in some idioms (MOON 1998), occurs by means of stone as a verb.

Though we can qualify them as wordplay due to the manipulation criterion, $3 R$, $3 S$ and $3 T$ seem to be the most effective ones. In $3 T$, the wordplay is intensified by the double reading of stoned, "attacked/killed with a stone" or "under the influence of alcohol or drugs". 
Table 8: Other types and hybrid cases of modification based on matar dois pássaros ...

\begin{tabular}{c|l|c|c}
\hline \multicolumn{2}{l|}{} & $\begin{array}{r}\text { category } \\
\text { number of } \\
\text { occurrences }\end{array}$ \\
\hline $4 \mathrm{~L}$ & $\begin{array}{l}\text { Matar dois coelhos de uma cajadada só? } \\
\text { (Kill two rabbits with only one blow?) }\end{array}$ & $\begin{array}{l}\text { Será que o presidenciável está querendo matar dois } \\
\text { coelhos, com uma chibatada só? } \\
\text { (Is the presidential candidate wishing to kill two rabbits } \\
\text { in only one blow with a whip?) }\end{array}$ & $\begin{array}{c}\text { substitution + } \\
\text { polarity }\end{array}$ \\
\hline $4 \mathrm{~N}$ & $\begin{array}{l}\text { Bolsonaro, cajadada em 3 coelhos: desassossego de } \\
\text { Moro } \\
\text { (Bolsonaro, a blow with a rod in 3 rabbits: Moro's } \\
\text { uneasiness) }\end{array}$ & $\begin{array}{c}\text { allusion + } \\
\text { substitution + } \\
\text { inversion }\end{array}$ & 1 \\
\hline
\end{tabular}

In Portuguese, $4 \mathrm{~L}$ and $4 \mathrm{M}$ are cases in which the idiom is used in the interrogative form (polarity), $4 \mathrm{~N}$ is by far a very interesting occurrence, it substitutes number two by three, symbol, and inverts the position of cajadada.

Two other occurrences (one in English and one in Portuguese) caught our attention: feed two birds with one scone, and alimentar dois coelhos com uma só cenoura (feed two rabbits with only one carrot). First impressions might suggest interpreting them as cases of reliteralization (remotivation or decrystallization) as discussed above; however, we have chosen to classify them as cases of "idiom revitalization" 5 .

Like in instances of reliteralization in which "a literal meaning of one of the components must be invented in order to achieve the desired effect" (COULMAS 1979: 145), instances of revitalization preserve the overall phraseological skeleton, making use of "reinvented" components of the canonical form. However, differently from reliteralized forms, in which the same underlying conceit, in this case, "achieving two goals in one single action", is maintained following the same allusion ("putting animals to death"); in revitalized idioms, there is a different perception of this idea. There occurs a shift in orientation - from a negative to a positive circumstance -, it also alludes to animals, which are no longer "killed/(-)", but "fed/(+)". The two

5 It should not be confused with the expression "idiomatic revitalization", "language revitalization", "language revival", or "reversing language shift", an attempt to halt or reverse the decline of a language or to revive an extinct one.

TradTerm, São Paulo, v.37, n. 2, janeiro/2021, p. 460-487

Número Especial - Linguística de Corpus

www.revistas.usp.br/tradterm 
expressions are the result of campaigns recently launched by PETA (People for the Ethical Treatment of Animals, USA), and PAN (People, Animals and Nature, Portugal), recommending that derogatory animal-related idioms should be replaced with animal-friendly expressions. In line with this initiative, pregar dois pregos de uma martelada só ${ }^{6}$ (to drive in two nails with only one hammer hit) was also found in European Portuguese.

The difference in the behavior of idioms, in terms of variation, "could be explained by general rules that are derived mainly from the properties of the semantic structure of idioms”, and “(s)uch rules may help understand why certain types of variation occur with certain idioms but not with others". (ABDOU 2012: 103)

As far as the translation of canonical, noncanonical and alternative forms is concerned, we suggest that the translator can resort to corresponding pragmatic structures in the other language.

Tables 9 and 10 show the translation possibilities considering phraseologisms 1 and 2.

Table 9: Phraseologism 1: "canonical” and alternative forms

\begin{tabular}{l|l}
\hline Canonical form & \multicolumn{1}{c}{ Phraseologism 1 - English } \\
\hline Alternative forms & \begin{tabular}{l}
\multicolumn{1}{c}{ as lost as ... } \\
a duck in the desert \\
a little boy in a crowded mall \\
a toddler in a supermarket \\
an economics professor in an ethics class \\
a toothbrush at a redneck convention \\
as lost as a townie at the tailgate party \\
Alice down a rabbit hole \\
a nun on honeymoon \\
a newborn baby bird \\
a tenderfoot \\
the City of Atlantis
\end{tabular} \\
\hline
\end{tabular}

\footnotetext{
${ }^{6}$ It was found while our results were being edited for interferences; however, it became a useful combination to justify some of our interpretations and suggestions.

TradTerm, São Paulo, v.37, n. 2, janeiro/2021, p. 460-487

Número Especial - Linguística de Corpus

www.revistas.usp.br/tradterm
} 
Table 10: Phraseologism 2: canonical, noncanonical and alternative forms

\begin{tabular}{l|l}
\hline Canonical form & \multicolumn{1}{c}{ Phraseologism 2 - Portuguese } \\
\hline Noncanonical forms & $\begin{array}{l}\text { mais perdido que ... } \\
\text { cachorro cego em tiroteio } \\
\text { cusco em tiroteio }\end{array}$ \\
\hline Alternative forms & $\begin{array}{l}\text { mais perdido que ... } \\
\text { bolacha em boca de banguela } \\
\text { cachorro em dia de mudança } \\
\text { charuto em boca de banguela } \\
\text { chave em bolsa de mulher } \\
\text { dinheiro em brecha de sofá } \\
\text { motorista sem carteira } \\
\text { que palhaço em dia de finados }\end{array}$ \\
\hline
\end{tabular}

In Table 11, the translation possibilities considering phraseologisms 3 and 4 are presented.

Table 11: Phraseologisms 3 and 4: canonical and noncanonical forms

\begin{tabular}{l|l|l}
\hline & \multicolumn{1}{|c|}{ Phraseologism 3 - English } & \multicolumn{1}{c}{ Phraseologism 4 - Portuguese } \\
\hline Canonical form & to kill two birds with one stone & matar dois coelhos de uma cajadada (só) \\
\hline $\begin{array}{l}\text { Noncanonical } \\
\text { forms }\end{array}$ & & $\begin{array}{l}\text { matar dois coelhos de uma cacetada (só) } \\
\text { matar dois coelhos de uma paulada (só) } \\
\text { matar dois coelhos de uma porretada (só) }\end{array}$ \\
& to feed two birds with one scone & $\begin{array}{l}\text { alimentar dois coelhos com uma só cenoura } \\
\text { pregar dois pregos de uma martelada só }\end{array}$ \\
\hline
\end{tabular}

In practical terms, this means that such phraseologisms have both intralingual and interlingual analogs. An analog is to be understood as a variant form which exhibits similar or comparable elements to one or more components of another form in general or in some specific feature.

When occasional instantiations associated with an idiom base structure are found in a text, translators, as expected, should consider the context, which will probably force them to render the combination literally and pragmatically. For example, kill two birds with one phone (advertisement)

TradTerm, São Paulo, v.37, n. 2, janeiro/2021, p. 460-487 Número Especial - Linguística de Corpus www.revistas.usp.br/tradterm 
would result in mate dois coelhos com um telefone. From the pragmatic point of view, birds will become rabbits, since the Portuguese fixed expression alludes to such animal. The other part, which refers to the device, will be translated in a literal fashion, the device (phone/telefone) must remain.

Whether the occurrences retrieved and analyzed here are canonical forms, noncanonical forms, alternative forms or occasional instantiations associated with an idiom base structure, they have been originated from considerably transparent combinations, those that hardly pose comprehension problems for language users. Similarly, when they are transformed, especially by means of substitution, addition, insertion and allusion, and result in wordplays, these are also more easily perceived. Consequently, if translators detect them, find possible analogs in the other language and can produce similar transformations, the same pragmatic effect will probably be achieved as well.

Comparing the overall results of the four phraseologisms, it is interesting to observe that, in the idioms, both slots [kill two birds]+[with one stone] and [matar dois coelhos]+[de/com uma só cajadada] underwent more variation, whereas, in the similes, the slots [as lost as] and [mais perdido que] remained unchanged. In our understanding, this is due to fact that [as lost as] and [mais perdido que] are more literal than the whole chunk of the idiom, and, according to ARNAUD, MANIEZ \& RENNER (2015: 140), metaphorical structures are more open to modifications. Investigating other types of similes and how variations of more opaque idioms behave in large corpora is a subject of speculation.

As mentioned before, the selection of the phraseologisms in this investigation was made on the hypothesis that they represented canonical forms, in both languages, that they were promising, potential candidates for manipulations, and that our searches would retrieve noncanonical forms, resulting in wordplay. From the results obtained and further analyses, we have now somewhat different views:

First, our searches could retrieve not only noncanonical forms, but also alternative forms of idioms, and occasional instantiations associated with an

TradTerm, São Paulo, v.37, n. 2, janeiro/2021, p. 460-487 Número Especial - Linguística de Corpus www.revistas.usp.br/tradterm 
idiom base structure, proving that the phraseologisms selected are susceptible to some kind of variation or exploitation;

Second, phraseologism 1, as lost as a duck in the desert, is unlikely to be a canonical form, but is probably simply an alternative form among similar structures $(1 \mathrm{~A}$ to $1 \mathrm{~N})$ available in the language;

Third, phraseologism 2, mais perdido que cego em tiroteio, can be considered a canonical form (highly frequent and found in specialist dictionaries); $2 \mathrm{E}$ and $2 \mathrm{H}$ can be considered noncanonical forms, and the others, alternative forms;

Fourth, the canonical form for phraseologism 3 appears to be kill two birds with one stone, all the other occurrences are occasional instantiations associated with an idiom base structure, resulting from creative contextmotivated constructions, except feed two birds with one scone, which seems to be its real noncanonical form; and

Fifth, phraseologism 4, matar dois coelhos de/com uma cajadada só, is a canonical form, and instances, like matar dois coelhos de uma cacetada/paulada/porretada só, can be considered noncanonical forms as well as alimentar dois coelhos com uma só cenoura and pregar dois pregos de uma martelada só; others than these are occasional instantiations resulting from creative context-motivated constructions.

Considering occasional instantiations associated with canonical forms, it seems that readers/listeners analyze the combinations both noncompositionally and compositionally. Based on the context, they decide which elements should be interpreted metaphorically, mainly the ones related to the canonical form, and then, they decide which part refers to an external element, in general, non-symbolic. For example, kill two birds with one phone (advertisement for a cellular phone); evidently, "no fowl is killed with the device" (reference to the canonical form versus reference to an external element). The new combination is equally interpreted as figurative by readers/listeners, who recognize it as relating to the canonical form. 


\section{Concluding remarks}

As we have observed, not all the occurrences collected and analyzed here can qualify as wordplay. However, both noncanonical forms and occasional instantiations associated with a base idiom structure can constitute wordplay if they exhibit manipulated elements of the standard form. We reinforce the idea that any type of manipulation of the conventionalized use of a linguistic structure, which results in wordplay, is not primarily intended for causing a comic effect, but an effect of surprise, resulting from a construction contrary to expectation. It serves as an initial effect that can trigger subsequent effects of humor, criticism, and so on.

After encountering and analyzing idiom-based phraseologisms in large corpora, our contribution seems to have helped destroy the myth that they can only be retrieved by accident. It also confirms that nonstandard forms are indeed typical of journalism (highly frequent in sports and politics sections) and advertisement, in both languages; and that there is no ready-made formula for extracting such deviant forms, several search queries will have to be tried and combined, considering, above all, the keyness degree of each constituent of the combination.

In conclusion, if wordplay is lost in the jungle of words, the appropriate approaches, the proper tools and the right procedures will help researchers rescue them safe and sound.

TradTerm, São Paulo, v.37, n. 2, janeiro/2021, p. 460-487 Número Especial - Linguística de Corpus www.revistas.usp.br/tradterm 


\section{Acknowledgement}

I wish to express my heartfelt gratitude to Dr. Stella E. O Tagnin, who supervised my Master's and Doctor's research, and who has always encouraged me (in good and bad times) to move ahead with her extraordinary enthusiasm for and passionate interest in new theories, methodologies and technologies.

\section{References}

ABdou, A. Arabic Idioms. A corpus-based study. London and New York: Routledge, 2012.

ANTHONY, L. AntConc (Windows, Macintosh OS X, and Linux) Build 3.5.8, February 18, 2019. Available at: https://www.laurenceanthony.net/software.html/ (Jan 26, 2020)

Arnaud, P. J. L.; Maniez, F.; Renner, V. Non-Canonical Proverbial Occurrences and Wordplay: A Corpus Investigation and an Enquiry Into Readers' Perception of Humour and Cleverness. In: ZiRKER, A.; Winter-Froemel, E. (eds.), Wordplay and Metalinguistic/Metadiscursive Reflection: Authors, Contexts, Techniques, and Meta-Reflection, Berlin/Boston: De Gruyter, 2015: 135-159.

Aulete Digital. 0 dicionário da língua portuguesa na internet. Available at: http://www.aulete.com.br. (Feb 4, 2020)

BARTA, P. Au pays des proverbes, les détournements sont rois: Contribution à l'étude des proverbes détournés du français (I). Paremia, 14, Madrid, 2005, pp. 61-70.

BREZOLIN, A. O humor está no ar: análise comparativa da tradução de jogos de palavras fraseológicos em texto literário. Revista de Estudos da Linguagem, [S.l.], v. 28, n. 1, Belo Horizonte, 2020, pp. 359-389.

Brezolin, A. Pergunta se macaco quer banana! Breve análise de frases feitas jocosas: estudo da língua em uso com o auxílio da Linguística de Corpus. Tradterm, 12, São Paulo, 2006, pp. 127-157.

Brezolin, A.; Allegro, A. L. V.; Mobaid, R. Whatchamacallit? Novo dicionário português-inglês de idiomatismos e coloquialismos. São Paulo: Disal, 2006.

Brezolin, A.; Allegro, A. L. V.; Mobaid, R. Pequeno Dicionário de Expressões Idiomáticas e Coloquialismos: português-inglês. São Paulo: Fiúza Editoras, 2002.

TradTerm, São Paulo, v.37, n. 2, janeiro/2021, p. 460-487

Número Especial - Linguística de Corpus

www.revistas.usp.br/tradterm 
CAMARGo, S.; SteInBeRG, M. Dicionário de expressões idiomáticas metafóricas, São Paulo: McGraw-Hill, 1987.

CARNeIRO, R. M. O. O jeito que a gente diz: convencionalidade e idiomaticidade. Domínios de Lingu@gem, v. 11, n. 3, Uberlândia, jul./set. 2017, pp. 1075-1083.

CoUlmas, F. Idiomaticity as a problem of pragmatics. In: PARRET, H.; SBISA, M.\& Verschueren, J. (eds.), Possibilities and Limitations of Pragmatics (Proceedings of the Conference on Pragmatics, Urbino 1979), Amsterdam: John Benjamins, 1979, pp. 139-51.

DelabastitA, D. Introduction. Wordplay and Translation: Special Issue of 'The Translator', Manchester, v. 2, n. 2, p. 127-140, 1996.

DORE, $M$. The audiovisual translation of fixed expressions and idiom-based puns. In: VALERO-GARCÉS, C. (ed.). Dimensions of humor: explorations in linguistics, literature, cultural studies and translation, València: Universistat de València, 2010, p. 361-386.

GIORGADZE, M. Linguistic features of pun, its typology and classification. European Scientific Journal, Ponta Delgada/Kocani/Buenos Aires, Special Edition. v. 2, p. 271-275, 2014.

Granger, S.; Paquot, M., F. Disentangling the phraseological web. In: Granger, S.; MeUNIER, F. (eds.), Phraseology: an interdisciplinary perspective, Amsterdam/Philadelphia: John Benjamins, 2008, pp. 27-49.

GRIES, S. T. Phraseology and linguistic theory. In: GRANGer, S.; MeUnIER, F. (eds.), Phraseology: an interdisciplinary perspective, Amsterdam/Philadelphia: John Benjamins, 2008: 3-25.

KJeLLMer, G. A mint of phrases. In: AIJMER, K.; AltenBerg, B. (eds.), English Corpus Linguistics. Studies in Honour of Jan Svartvik. London and New York: Longman, 1991: 111-127.

MERRIAM-WEBSTER.COM. Available at: https://www.merriam-webster.com. (Feb 4, 2020)

Michaelis - Dicionário Brasileiro da Língua Portuguesa. São Paulo: Melhoramentos, 2015. Available at: https://michaelis.uol.com.br. (Feb 4, 2020)

Moon, R. Fixed Expressions and Idioms in English. Corpus Lexicography. Oxford: Clarendon Press, 1998.

PHILIP, G. Reassessing the canon - Fixed phrases in general reference corpora. In: Granger, S.; Meunier, F. (eds.), Phraseology: an interdisciplinary perspective, Amsterdam/Philadelphia: John Benjamins, 2008: 95-108.

TradTerm, São Paulo, v.37, n. 2, janeiro/2021, p. 460-487

Número Especial - Linguística de Corpus

www.revistas.usp.br/tradterm 
Renouf, A. J.; SinClair, J. Collocational frameworks in English. In: AlJmer, K.; Altenberg, B. (eds.), English Corpus Linguistics. Studies in Honour of Jan Svartvik, Harlow: Longman, 1991: 128-143.

TAGNIN, S. E. O. A tradução de suculentos jogos de palavras, sem perder o sabor. Revista de Estudos da Linguagem, v. 23, n. 3, Belo Horizonte, 2015a, pp. 681-693.

TAGNIN, S. E. O. O humor como quebra da convencionalidade. Revista Brasileira de Linguística Aplicada, v. 5, n. 1, Belo Horizonte, 2005b, pp. 247-257.

TAGNIN, S. E. O. O jeito que a gente diz: combinações consagradas em inglês e português. São Paulo: Disal, 2013.

The Collins COBUILD DictionaRy OF IDIOMS, London, Glasgow: HarperCollins, 1995. (Feb 4, 2020)

The Free Dictionary. Available at: https: / / www.thefreedictionary.com. (Feb 4, 2020)

VeIsBergs, A. The contextual use of idioms, wordplay, and translation. In: DelabastitA, D. (ed.). Traductio: Essays on Punning and Translation, Manchester: St. Jerome Publishing, 1997, p. 155-176.

VIÉGAS-FARIA, B. Soluções tradutórias para a alteração contextual de provérbios em Júlio César, de Shakespeare. Letras de Hoje, v. 39, n. 1, Porto Alegre, 2004, pp. 195-214.

Recebido em: 25/03/2020

Aceito em: 23/04/2020

Publicado em janeiro de 2021

TradTerm, São Paulo, v.37, n. 2, janeiro/2021, p. 460-487

Número Especial - Linguística de Corpus

www.revistas.usp.br/tradterm 


\section{Appendix I}

\section{AntConc concordance lines of "kill two birds with one stone" occurrences}

ogramme? The Food Bank programme actually aims to kill two birds with one stone. See Also. Uncategorized ...

... As much as it would be simple to kill two birds with one stone and reveal ... Why

: As much as it would be simple to kill two birds with one stone and reveal Jamal that the campaign, which runs for 30 days, will kill two birds with one stone, bolstering ad revenue driving ... Wireless earbuds are a great way to kill two birds with one stone. Whether you're ation, administration thought it would be wise to kill two birds with one stone and move up ume and destination reshuffle, the Saudis look to kill two birds with one stone. One goal is onversational Commerce businesses will be able to kill 'two birds with one stone' by keeping customers

... With the new vehicle, the carmaker plans to kill two birds with one stone and launch a . With this initiative the UP Police aims to kill two birds with one stone, spread awareness about museum in Camp Ripley were looking to kill two birds with one stone. Yahoo Entertainment-Nov 17, 2019 out of the ... Rip took the moment to kill two birds with one stone and ask Walker ...

h ... Yes, he completely annihilates the classic "kill two birds with one stone" saying, but the general manager Kevin Cheveldayoff would love to kill two birds with one proverbial stone in either attempts to take advantage of Shiny Chaining to kill two birds with one stone. You Can Go sprinkle is in the garden, so you could kill two birds with one stone by waiting until jute or hemp. It's extraordinary what ... Denver: Kill two birds with one stone. Ingrid: Yes. It' :Yes. It's: Feed two ... You get to kill two birds with one stone here. You have way to the airport or you want to kill two birds with one stone and get a you may as well run that first to kill two birds with one stone. Run your activity

\section{AntConc concordance lines of "as lost as" occurrences}

... "The first 31 years of my life, I was as lost as a duck in the desert," Sadowski together ...... of the first book, you may feel as lost as a townie at the tailgate party.... anyone else. ... you begin to feel you are as lost as a white fella can be in have dropped five straight and nine of 10, look as lost as a seven-day-old puppy released Lewton at the Stanford Theatre CBR Cejudo looked as lost as a newborn baby bird. Stuck at

lost as Brandon Weeden that ... I'm just as lost as a lot of people. I got been a little bit hectic. I'm just as lost as a lot of people. I got been a little bit hectic. I'm just as lost as a lot of people. I got

our last two matches our beloved team looks as lost as a Hitch Hiker from Timbuktu with for dessert. ... yourself konuya Frans?z kald?m, "as lost as a French person," as the old not pick up the fact that you are as lost as a toddler in a ... Kentucky Completes

-subtle way of saying that you're just as lost as a donkey with its head in

than that though, the team has looked about as lost as a toothbrush at a redneck convention a podium finish in 2014 , he has sometimes looked as lost as a deer in headlights under ... Mother

but is not billed and is further considered as lost as a results of leaks or illegal ...

y in swipes at the government: "Conservatives are as lost as a ... Outside Magazine-Aug 21, 2013 Outside Magazin

that allows pet owners to list an animal as "lost" as a safeguard. Jones says she doesn'

' The first 31 years of my life, I was as lost as a duck in the desert, Sadowski

he lost his first six starts, sometimes looked as lost as a little boy in a crowded

as someone else ... When it did, I was as lost as a tenderfoot. Like Randy, who had

TradTerm, São Paulo, v.37, n. 2, janeiro/2021, p. 460-487

Número Especial - Linguística de Corpus

www.revistas.usp.br/tradterm 


\title{
AntConc concordance lines of "matar dois coelhos ..." occurrences
}

\author{
que bandidos e corruptos se destruam, matando dois coelhos com uma cajadada só, como sugere \\ , "a administração de Trump está tentando matar dois coelhos com uma cajadada: chegar a um \\ que mais engordam, então é como matar dois coelhos com uma cajadada só.... libertas de \\ pelo Universo Marvel comum. Nada como matar dois coelhos com uma martelada ... ... matar o boleto \\ os, interior de ....... o município poderia matar dois coelhos com uma cajadada só e encorajar \\ Esteves), que armará uma arapuca para matar dois coelhos com uma só cajadada em Segundo \\ e percebe que essa situação pode matar dois coelhos com uma cajadada ... ... possa prevenir o \\ com a língua de Shakespeare e matar dois coelhos com uma cajadada só.... que pode \\ .... que pode fazer a humanidade matar esses dois coelhos com uma cajadada só: 0 ambiente \\ débito automático? Isso seria igual a matar dois coelhos com uma cajadada só (não mate \\ do Paços tinham a expectativa de matar dois coelhos com uma cajadada.... RECURSOS PARA FÃs \\ MAUÁ E SANTO ANDRÉ. ELE TENTA MATAR DOIS COELHOS COM UMA CAJADADA SÓ.... Sadako Vs \\ , cheguei a especular que você poderia matar dois coelhos com uma só cajadada e mandar \\ Paloma (Grazi ... da moça para tentar eliminar dois coelhos com uma cajadada só. ... seus especialistas \\ para a estrada de Mangabeira para matar dois coelhos com uma obra só. Tanta demolição, \\ academia e, pelo visto, aproveitou para matar dois coelhos com uma saída só. Deixou a \\ de coelho ... A Casa Branca quer matar dois coelhos com uma só paulada. A suposta \\ novos testes, ... A China está tentando matar dois coelhos com uma só cajadada transformando resíduos \\ janeiro, ... A fome bateu e para matar dois coelhos com uma só cajadada, siga rumo
}

\section{AntConc concordance lines of "mais perdido que" occurrences}

que tentou ser técnıco e viu tava maıs perdıdo que cego e tıroteı e acabou primeiros dias de governo, Bolsonaro mostrou-se mais perdido que charuto na boca de banguela. e vira piada nas redes Galvão Bueno mais perdido que chave em bolsa de mulher mília, ... O presidente Jair Bolsonaro (PSL) está mais perdido que chinelo de bêbado na crise ser cego. Voto Positivo00Voto ... Vc está mais perdido que cusco em tiroteio Macri não de poço" - com 15,98\% dos votos -, seguido por " mais perdido que cusco em tiroteio" ... O ser Notícias (Blogue)-9 de abr. de 2019 Vc está mais perdido que cusco em tiroteio Macri não .Kkk pic.twitter.com/UQvXa4w1ux. Mais perdido que dinheiro em brecha de sofá (@ quer começar com a arte, mas está mais perdido que Drek'Thar em tiroteio. ... muito ma têm reencontro dramático com Marcos ... Bonner mais perdido que eu quando levei a bandeja todo lado ..Kd a assistência social?não ... Mais perdido que eu, escreveu um no Twitter. que esclarecer as questões de quem está mais perdido que eu lamentou Fuenti. A inspeção ...

muito , e o restante do grupo está mais perdido que motorista sem carteira.... impeachment de

i 0 não gostei 0 . Responder. Esse governador esta mais perdido que nem cego em tiroteio, primeiro ja estaria ruim, agora ... Esse governador esta mais perdido que nem cego em tiroteio, primeiro para estimular as vendas ... O governo ta mais perdido que nunca pra mim esta reforma irmãos numa "road trip" pela ... "Eu tô mais perdido que o Bolsonaro na presidência", ironizou você ainda não preencheu o bolão? Está mais perdido que o pessoal de Black Mirror ... sociais para acertar os relógios. Eu tô mais perdido que o Bolsonaro na presidência, ironizou

TradTerm, São Paulo, v.37, n. 2, janeiro/2021, p. 460-487 Número Especial - Linguística de Corpus www.revistas.usp.br/tradterm 